\title{
Problems of English for Specific Purpose course for medical students in Iran
}

\author{
Alireza Boniadi, \\ Islamic Azad University of Uromia
}

Morteza Ghojazadeh, Tabriz University of Medical Sciences

Neda Rahmatvand

Tabriz University of Medical Sciences

\section{Introduction:}

English plays an eminent role in higher education all over the world. There has been a worldwide growth in demand for English for Academics courses (Jordan, 1997). English, the lingua franca of all sciences, has come out in non-English speaking countries as English for Specific Purposes (ESP) (Ghanbari, 2010). ESP is a developing branch of English as a Foreign Language (EFL) instruction in Iran (Moslemi, Moinzadeh \& Dabaghi, 2011). A significant aspect of language instruction on the higher educational level is learning English for a given purpose, with the specific aims of getting to know specialized vocabulary, increasing one's knowledge about the subject matter by reading in English, and being able to use the language in the prospective profession or study area by becoming prepared for some common situations such as carrying out higher level studies, going for an interview or conducting professional communication (Varnosfardani, 2009). Many English language courses in academic settings are based on the principle that language should be related to the purpose for which students are expected to use language after their studies. An ESP course for medical students intends to help them study their subject matter and in their career in the future. It seems that English plays a very vital role in medical studies because the students have to read medical textbooks and professional journals which are mostly written in English (Bensoussan, Collado, Viton \& Delarque, 2009).

After the Islamic Revolution in Iran (1978), there has been a doctrinaire move supervised by the Ministry of Science, Research, and Technology (MSRT) to set up identical discipline-based EAP programs for academies (Eslami, 2010). 
Problems of English for Specific Purpose courses in Iran are: they are being offered without advanced planning in course design, systematic needs analysis, teacher education, time, textbooks, and systematic research on the effectiveness of these programs (Eslami, 2010; Karimkhanlouei, 2012, Hayati, 2008).

Despite the importance of ESP courses for students in Iran, especially medical students, there have been very rare studies that generally and specifically examined the English language needs of medical students. English has so far been taught without a systematic survey of the needs of the medical students (Eslami, 2010, Karimkhanlouei, 2012).

So, careful examination of the expectations and perceptions of learners and instructors is seen to be important in determining the success of ESP courses. There has been no formal survey of the needs and expectations of medical students in using English for specific purposes courses in Tabriz University of Medical Sciences. In order to understand as much about the learners as possible, an investigation of the formal needs analysis of the medical students and instructors in their use of academic English is essential. These needs will then serve as a guide to improve or expand the existing English programs, so that more effective English courses will be created for the medical students in the future.

This paper addresses the issue of learners and instructors' preferences and expectations of the main problems of ESP classes in the school of medicine. The investigation aimed at gathering such data from the students and their teachers at university and observing ESP classes to make informed decisions to ensure effective language learning.

\section{Methodology:}

This study was conducted at the medical faculty of Tabriz University of Medical Sciences, one of the major universities in Iran. Due to constraints in terms of time, distance and accessibility, the needs analysis conducted in this study only obtained feedback from the students and the lecturers who are academically involved with these ESP students at medical faculties of Tabriz University of Medical Sciences.

Both quantitative and qualitative approaches were considered to produce a more accurate interpretation of the data.

The qualitative approach was carried out via ESP class observation and semistructured interviews with the ESP lecturers involved in teaching this ESP course. Initially, classroom observation was conducted during an ESP lesson according to 
Hutchinson and Waters' checklist. Secondly, the semi- structured interviews were conducted in the instructor's office. Respondents were asked to comment on the content of the course, the materials used, teachers' classroom practices and general problems they encountered. With this instrument, teachers' insights about the program were obtained. The duration of the interviews varied from 10 to 15 minutes. The interviews were conducted in Persian.

As for the quantitative phase of this study, a questionnaire was designed to collect data. The questionnaire used in this study was constructed by the researcher according to other related studies in electronic and non-electronic recourses. The items were ranked on a Likert Scale ranging from 1 (least important) to 4 (most important). The validity of this questionnaire was evaluated by content validity and using factorial analysis for examining construct validity. Reliability of this questionnaire was evaluated by Cronbach's Alpha. The values for the total questions were 0.74 , which is a good value.

In total, 5 teachers (both male and female) participated in the study. They held $\mathrm{PhD}$ degrees in Biochemistry, Physical Medicine, Microbiology, Epidemiology and Dentistry, with their age ranging from 40 to 55 . The participants' teaching experience was from 13 to 19 years. They had taught ESP courses for students in medicine, dentistry, and pharmacy faculties as well.

The study included 200 third-year medical students from the Faculty of Medicine in Tabriz University of Medical Sciences. $125(62.5 \%)$ were female and 75 $(37.5 \%)$ were male. The students' age ranged from 19 to 25 with a mean of 20 .

\section{Result and Discussion:}

The data from the questionnaires was analyzed by using the SPSS programme, version 16. Mainly descriptive statistics were used. The mean, percent, frequency and Standard Deviation of questions were obtained. The semi-structured interviews were conducted by instructors and their answers were tape-recorded. All responses were transcribed and then translated into English. The interviews were subjected to content analysis. Data obtained from the teachers were categorized and discussed under the subtitles of Importance of using English, evaluation of ESP course and problems of ESP courses.

Results of observation of ESP classes indicated that the ESP course was held in traditional classes. The surrounding was pleasant but these classes were too busy. Usually 40-50 students participated in each class. These classes took place twice a 
week. The teacher was making use of L1 to teach the content of the lesson. The teacher had authority in the classroom. ESP instruction was limited to training special vocabulary and reading and translating numerous texts. Of course, such methods didn't reflect students' interests and resulted in low motivation of learners and their poor participation. Medical Terminology and English for Medical Students, two textbooks, were used for teaching. Whatever the teacher taught was based on the content of books and some new vocabularies. The teachers taught medical vocabulary with little attention to listening and speaking skills. Communicative activities and authentic communication in real life were neglected, which is a big problem. The instruction was boring to the students on the whole. One of the negative effects of the teaching process was the monotonous style of the instruction which caused students to feel bored with the lesson.

The results of interviews with instructors indicated that teachers regarded English language as important in medical fields because science is changing and developing and English is the lingua franca of medical sciences. Translation of new medical reference books and participation in the international community made learners fluent in the English language. Instructors selected materials according to the needs of students, authenticity of materials and books that were introduced by Ministry of Health and Medical Education. Some of the instructors agreed with the current methods of teaching in ESP classes at the faculty of medicine in Tabriz University of Medical Sciences and some of them did not. But all of them thought it could be on a better level and it should be improved. They had innovative ideas for improving the quality of teaching of ESP. They emphasized that experimenting with new methods of English language teaching based on communicative language teaching should affect the methods of teaching in universities in Iran and teachers should try to avoid using traditional methods of teaching such as grammar and translation. Problems of ESP classes according to students include: size of class, uninterested and unmotivated students, tiredness of students, low proficiency of students, credits of course, audio visual aids, heterogeneous students (mixed professional), and inactivity of students in classes. Most of the instructors believed that the inactivity of students was because of low English language proficiency of medical students. All of the instructors believed that the main reason for low language proficiency was the poor instruction presented to students during 12 years of study at primary schools in Iran. English instructors emphasized the necessity of changes in the students' English education. Most of the instructors believed that size of the classes was one of the important problems.

Results of the questionnaire showed that students who participated in the present study were university students of medical sciences. Most of them were in their third year of study. From all the students participating in the study, of a total 200, 
$125(62.5 \%)$ were female and $75(37.5 \%)$ were male. Their mean age was $20.25 \pm$ 0.64 . The minimum age was 19 and maximum was 22 . Most of the students were 20 years old. The results indicate that $(55.1 \%)$ of students slightly agree with methods of teaching, (23.7\%) somewhat agree, (17.7\%) don't agree at all and $(3.5 \%)$ of participants very much agree with the methods of teaching. The majority of students (54\%) think teachers pay little attention to their needs, $(24.0 \%)$ believe somewhat, $(16.5 \%)$ not at all and $(5.5 \%)$ believe teachers pay very much attention to their needs and expectations.

Problems

Figure 2 Bar chart of ESP classes' problems

Figure 2 shows that $(78 \%)$ of participants think boring classes are the first problem in ESP classes, (55\%) think use of outdated material, (45\%) think low level of English language ability of students (English proficiency), (42\%) think overcrowded classes, (38\%) think low level of English knowledge of teachers, (37\%) think low level of subject knowledge of teachers, (28\%) think limited vocabulary, $(25 \%)$ think class activity of students, $(22 \%)$ think slow speed of reading, (20\%) think lack of audiovisual material, and (17\%) think lack of audiovisual material is the main problem of ESP classes.

\section{Conclusions:}

With regard to the examination of English language problems that students were currently facing in their academic studies, boring classes, low English proficiency, and overcrowded classes were rated as the main problems.

The majority of instructors believed that the size of classes, uninterested and unmotivated students, inactivity and low proficiency of students are the main problems in the ESP course.

Concerning the question of credit, both groups of subjects agreed that the number of credits for the ESP course were not enough for them.

For the size of the class, both groups of subjects selected overcrowded classes as the main problem. This agrees with the idea that the less students, the better the teaching / learning. But in real situations, there are more than 30 students (usually $40-60)$ in the classroom. In studying any language, researchers think that the language classroom shouldn't be more than 25 . Hence, the teacher can handle the class more effectively (e.g. correct students' mistakes, comment on students' 
performance and activity of students). It is also easier for the teacher to discuss with the students what they have been taught in the class or any other topics which may help enhance the students' knowledge. Of course, students have more opportunity to practice various skills or tasks in the classroom if the class size is small.

Limited vocabulary, negative attitudes toward English, lack of availability of audio-visual materials, and outdated textbooks and materials were other areas in which there was a significant difference between the instructors and the students. Students perceived these problems as being more important than instructors did.

On the other hand, instructors perceived the lack of student involvement and participation in class activities to be significantly more important than students did. A likely explanation is that since English Language Teaching faculty members believed students do not participate in class activities as much as they should, and with the students' low English language proficiency, more teacher-centered classes are required to effectively teach large ESP classes.

From the researchers' point of view, the medical students had problems not only in reading skills but also in other skills: speaking, listening and writing. Although the medical students have been studying English for many years in schools, they still face problems in communicating in English, or coping with their English in other academic fields. Another factor was that the students did not have much opportunity to use English in their daily lives. The situation in Iran does not support their English learning.

Similarly, students' ranking of boring classes and excessive use of translation activities as problematic areas was significantly higher than instructors' ranking. Teachers might therefore need to apply diverse communicative activities in language classrooms to give EAP students opportunities to practice using English in a different context and focus more on self-regulated learning.

To sum up the feedback of the opinions obtained from the two groups of subjects towards their perception of ESP courses at the faculty of medicine, they all agreed that the current English courses provided for the medical students are not relevant to the academic needs of the students. More English courses which are academically specific to their field are urgently needed and in addition, all the macro skills (reading, writing, speaking and listening) and especially communication skills should be included in ESP course. 


\section{References and Notes}

1. Bensoussan, L., Collado, H. Viton, M., Delarque, A. (2009). Should European PRM residents be taught in English? The experience of the European School Marseille. Annals of Physical and Rehabilitation Medicine, 52, 729-745.

2. Eslami, Z.R. (2010). Teachers' voice vs. students' voice: A needs analysis approach to English for academic purposes (EAP) in Iran. English Language Teaching, 3(1), 3-11

3. Ghanbari, B. (2010). ESP Practitioner Professionalization through Apprenticeship of Practice: The Case of Two Iranian ESP practitioners. English Language Teaching, 5(2), 112-122.

4. Hayati, M. (2008). Teaching English for Special Purposes in Iran Problems and suggestions. Arts \& Humanities in Higher Education., 7(2), 149-164.

5. Hutchinson, T. \& Waters, A. (1987). English for Specific Purposes: A learner-centered approach. Cambridge: Cambridge University Press.

6. Jordan, R.R. (1997). English for academic purposes: a guide and resource book for teachers. Cambridge, UK and New York: Cambridge University Press.

7. Karimkhanlouei, G. (2012). What do Medical Students Need to Learn in Their English Classes. Journal of Language Teaching and Research, 3(3), 571-577.

8. Moslemi, F., Moinzadeh, A., Dabaghi,A. (2011). ESP Needs Analysis of Iranian MA students: A Case Study of the University of Isfahan. English Language Teaching, 4(4), 121-129.

9. Varnosfadrani, A.D. (2009). Teaching English for Specific Purposes. In: Reinelt, R. (Ed.), Into the Next Decade with (2nd) FL Teaching. Rudolf Reinelt Research Laboratory EU Matsuyama, Japan, p.181-201. 


\title{
Summary \\ Problems of English for Specific Purpose course for medical students in Iran Alireza Boniadi, \\ Islamic Azad University of Uromia
}

\author{
Morteza Ghojazadeh, \\ Tabriz University of Medical Sciences \\ Neda Rahmatvand \\ Tabriz University of Medical Sciences
}

It is now widely accepted that the English language has become the language of international communication. The widespread need for English as a second or foreign language puts a great pressure on the educational resources of many countries. ESP courses require specific language and skills that are related to communities of practice and disciplines. Careful examination of the attitudes and perceptions of learners and instructors is seen to be important in determining the problems of ESP courses. This study focuses on an ESP course offered at Tabriz faculty of Medical Sciences in Iran. The instruments used in this study were questionnaires for 200 medical students, interviews with 5 teachers and observation by the researcher. The data from the questionnaires was analyzed by using the SPSS programme, version 16. Results showed that ESP instruction was limited to training special vocabulary and reading and translating numerous texts. Of course, such methods didn't reflect students' interests and resulted in low motivation of learners and their poor participation. This study assumes that the English language is used widely in the medical field. Therefore ESP courses for medical students should be based on target needs of students representing communicative use of language rather than linguistic categories.

Key words: ESP course, medical students, English as a Second Language, teaching methods, ESP teaching 